\title{
Equilibrium Studies and Kinetics Mechanism for the Removal of Congo red by Passiflora Foetida Activated Carbon-Mnoz- Nano Composite
}

\author{
M.Sathya ${ }^{1}$, P.E.Kumar ${ }^{2 *}$ and M.Santhi ${ }^{2}$ \\ ${ }^{1}$ Research Centre, Bharathiar University, Coimbatore-641046, Assistant Professor of Chemistry, \\ Nandha College of Technology, Erode-638052, T.N., India. \\ ${ }^{2 *}$ Associate Professor of Chemistry, Erode Arts and Science College, Erode-638 009, T.N., India. \\ ${ }^{2}$ Assistant Professor of Chemistry, Erode Arts and Science College, Erode-638 009, T.N., India.
}

\begin{abstract}
This paper presents the feasibility of removal of Basic dye (Congo Red) from aqueous solutions by using a low cost PAC-MnO ${ }_{2}-\mathrm{NC}$. Batch adsorption experiments were carried out as a function of $\mathrm{pH}$, contact time, initial concentration of the adsorbate, adsorbent dosage and temperature. Pseudo first order, Pseudo second order, intra-particle diffusion model and Elovich kinetic models were studied. Thermodynamic parameters such as $\Delta H^{\circ}, \Delta S^{\circ}$, and $\Delta G^{\circ}$ were also calculated.
\end{abstract}

Keywords: Congo Red, $\mathrm{PAC}-\mathrm{MnO}_{2}-\mathrm{NC}$, Kinetics.

\section{Introduction}

The textile industries are becoming a major source of environmental contamination, because an alarming amount of dye pollutants are generated during the dying processes [1]. Dye bearing effluent is a significant source of water pollution. Dyes are mainly classified into cationic, anionic and non-ionic dyes. These effluents can cause potential pollutants to human beings and aquatic life. Various physical, chemical and biological separation technologies are used in the removal of these effluents [2]. All of these methods have their own advantages and disadvantages. The method of elimination of dyes using a variety of activated carbon is widely studied, but it was economically expensive [3]. Therefore much interest has focused on methods of adsorption by using natural materials and upgraded wastes [4].

Literature survey shows that various bio adsorbents have been used by researchers such as animal bone [5], black tea leaves [6], cocoa [7], almond shell [8], mango leaves [9], saw dust [10], Jambonut [11], Borassus flabellifer L[12] and Typha Angustata L[13]. Hence adsorption is recommended as a viable means for Basic dye removal.In the present work adsorption capacity of the passiflora foetida plant material [PAC- $\mathrm{MnO}_{2}-\mathrm{NC}$ ] was studied for the removal of Congo Red at different dye concentration, contact time, temperature, adsorbent dosage, $\mathrm{P}^{\mathrm{H}}$ and particle size. The adsorption dynamics and thermo dynamic parameters $\Delta \mathrm{H}^{\circ}, \Delta \mathrm{S}^{\circ}$, and $\Delta \mathrm{G}^{\circ}$ for such systems have been evaluated.

\subsection{Preparation of Activated Carbon}

\section{Materials And Methods}

The Passiflora foetida plant materials were collected from local area situated at Thindal, Erode District, Tamilnadu. They were cut into small pieces and dried for 20 days. Finally it was taken in a steel vessel and heated in muffle furnace. The temperature was raised gradually upto $500^{\circ} \mathrm{C}$ and kept it for half an hour. The carbonized material was ground well and sieved to different particle size. It was stored in a plastic container for further studies. In this study particle size of 0.15 to $0.25 \mathrm{~mm}$ was used and it was labeled as PAC.

\subsection{Preparation of $\mathrm{PAC}-\mathrm{MnO}_{2}-\mathrm{NC}$}

Activated Carbon (3gm) was allowed to swell in $15 \mathrm{~mL}$ of water-free Alcohol and stirred for 2 hours at $25^{0} \mathrm{C}$ to get uniform suspension. At the same time, the Maganese dioxide (3gm) was dispersed into water-free Alcohol $(15 \mathrm{~mL})$. Then the diluted Maganese dioxide was slowly added into the suspension of activated Carbon and stirred for a further 5 hours at $25^{\circ} \mathrm{C}$.To this, $5 \mathrm{~mL}$ alcohol and $0.2 \mathrm{~mL}$ of deionised water was slowly added. The stirring was continued for another 5 hours at $25^{\circ} \mathrm{C}$ and the resulting suspension was kept overnight in a vacuum oven for 6 hours at $80^{\circ} \mathrm{C}$.It was labelled as $\mathrm{PAC}-\mathrm{MnO}_{2}$-NC.

\subsection{Preparation of sorbate}

Congo red is purchased from S.d. fine chemicals. CR has molecular formula $\mathrm{C}_{32} \mathrm{H}_{22} \mathrm{~N}_{6} \mathrm{Na}_{2} \mathrm{O}_{6} \mathrm{~S}_{2}$. The dye concentration in supernatant solution was determined at characteristic wavelength $[\lambda \max =500 \mathrm{~nm}]$ by double beam UV-visible spectrophotometer [Systronics 2202]. Congo red is the sodium salt of 3,3'-([1,1'- 
biphenyl]-4,4'-diyl)bis(4-aminonaphthalene-1-sulfonic acid)( molecular weight: $696.66 \mathrm{~g} / \mathrm{mol}$ ). It is a secondary diazo dye. Congo red is water-soluble, yielding a red colloidal solution. The Chemical structure of Congo red is given below.

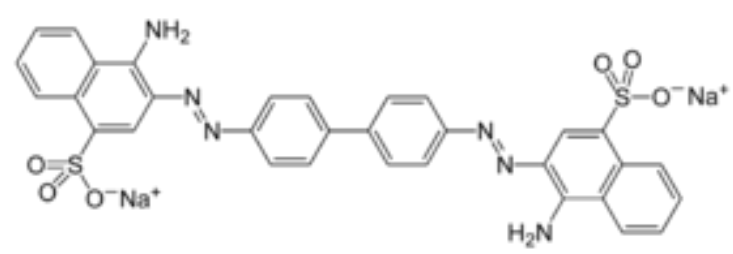

\subsection{Adsorption studies}

Batch method was followed by agitating $50 \mathrm{ml}$ of four different dye solutions (10, 20, 30 and $\left.40 \mathrm{mgL}^{-1}\right)$ at their natural $\mathrm{pH}$ with $100 \mathrm{mg}$ of $\mathrm{PAC}-\mathrm{MnO}_{2}-\mathrm{NC}$ in $150 \mathrm{ml}$ stoppered conical flasks at room temperature $\left(30 \pm 2^{\circ} \mathrm{C}\right)$ in a temperature controlled water bath shaker at $140 \mathrm{rpm}$. The samples were withdrawn from the shaker at predetermined time intervals and the dye solution was separated from the adsorbent by centrifuging at $10,000 \mathrm{rpm}$ for $10 \mathrm{~min}$. The absorbance of supernatant solution was measured using UV-VIS spectrophotometer (Cyber Lab, 100) at wave length $500 \mathrm{~nm}$. The amount of CR adsorbed per unit mass was calculated from the following equation:

$$
\mathrm{q}_{\mathrm{t}}=\frac{\left(\mathrm{C}_{\mathrm{O}}-\mathrm{C}_{\mathrm{t}}\right) \mathrm{V}}{\mathrm{W}}
$$

Where $\mathrm{q}_{t}$ is the amount of dye adsorbed per unit weight of adsorbent $(\mathrm{mg} / \mathrm{g})$; $\mathrm{C}_{\mathrm{o}}$ the initial concentration of $\mathrm{CR}(\mathrm{mg} / \mathrm{L}) ; \mathrm{C}_{\mathrm{t}}$ the concentration of $\mathrm{CR}$ solution at time $\mathrm{t}(\mathrm{min})$; $\mathrm{V}$ the volume of working solution $(\mathrm{mL}) ; \mathrm{W}$ is the adsorbent dosage $(\mathrm{mg})$. Blanks with only the adsorbate in $50 \mathrm{ml}$ of distilled water were conducted simultaneously at similar conditions to account for adsorption in using glass containers. It was found that no adsorption of $\mathrm{CR}$ by container walls occurred. The experimental parameters studied are adsorbent dosage, contact time, initial dye concentration, $\mathrm{pH}$ and temperature. Adsorption kinetics were tested with pseudo first-order, pseudo second-order, Intraparticle diffusion model, Elovich models.

\section{Results And Discussion \\ 3.1. Effects of agitation time and initial dye concentration of dye on adsorption}

Effects of agitation time and initial dye concentration (10, 20, 30 and $40 \mathrm{mg} / \mathrm{L})$ on removal of CR are presented in Fig.1. The percent removal of CR increased with increase in agitation time and reached equilibrium at $150 \mathrm{~min}$. The percent dye removal at equilibrium decreased from 71.01 to 54.41 as the dye concentration was increased from 10 to $40 \mathrm{mg} / \mathrm{L}$. It is clear that the removal of dye depends on the initial concentration of the dye. The removal curves are single, smooth and continuous leading to saturation.

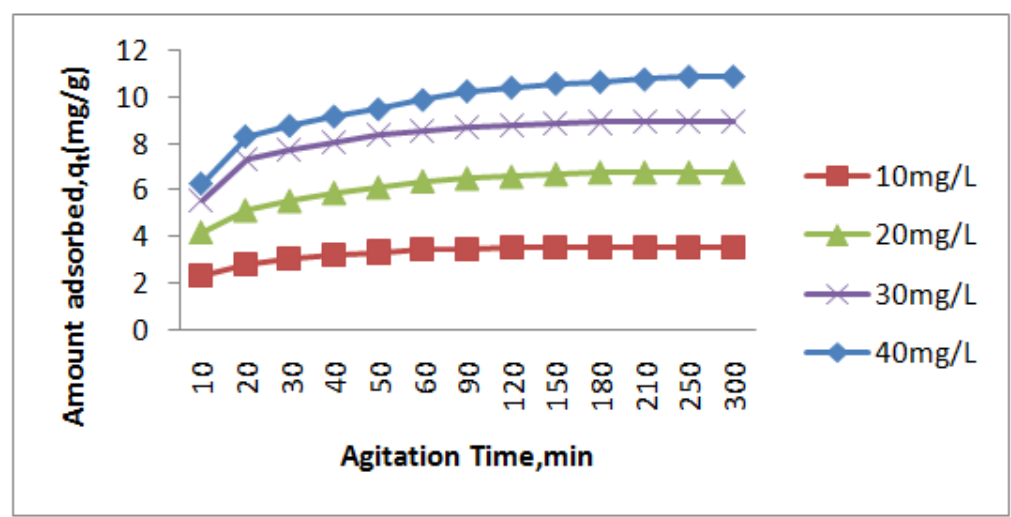

Fig.1. Effect of agitation time and concentration of CR on removal of

\section{PAC-MnO$-\mathrm{NC}$}

\subsection{Effect of adsorbent dose}

The removal of $\mathrm{CR}$ by $\mathrm{PAC}-\mathrm{MnO}_{2}-\mathrm{NC}$ at different adsorbent doses are presented in Fig.2. (10mg to $600 \mathrm{mg} / 50 \mathrm{ml}$ ) was tested for the dye concentrations 10, 20, 30 and $40 \mathrm{mg} / \mathrm{L}$. Increase in adsorbent dose increased the percent removal of dye which is due to the increase in surface area of the adsorbent. 


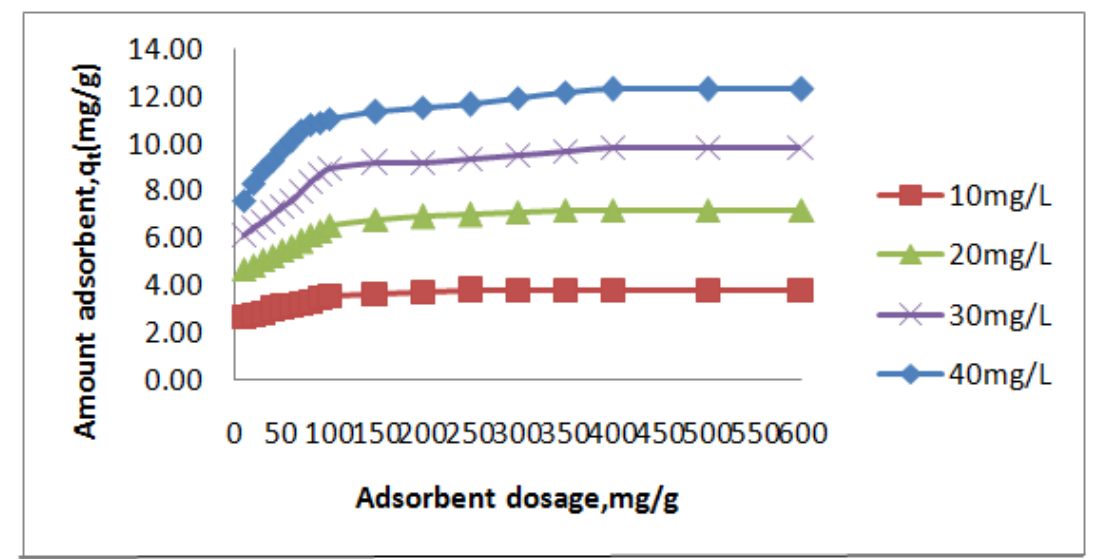

Fig.2.Effect of adsorbent dosage on removal of CR by $\mathrm{PAC}-\mathrm{MnO}_{2^{-}} \mathrm{NC}$

\subsection{Effect of $\mathrm{pH}$}

Effects of $\mathrm{pH}$ on the removal of $\mathrm{CR}$ by $\mathrm{PAC}-\mathrm{MnO}_{2}-\mathrm{NC}$ are shown in Fig.3. Dye adsorption decreases with increase of $\mathrm{pH}$ from 2 to 5 and no remarkable change there after. Low $\mathrm{pH}$ favors the adsorption, as decrease of $\mathrm{pH}$ the surface become more protonated and acquire positive charge which makes it easier for the anionic dyes to bind with carbon. Poor adsorption of $\mathrm{CR}$ at higher $\mathrm{pH}$ value is due to the competition between the negatively charged hydroxyl ions and anionic dye for the sorption sites.

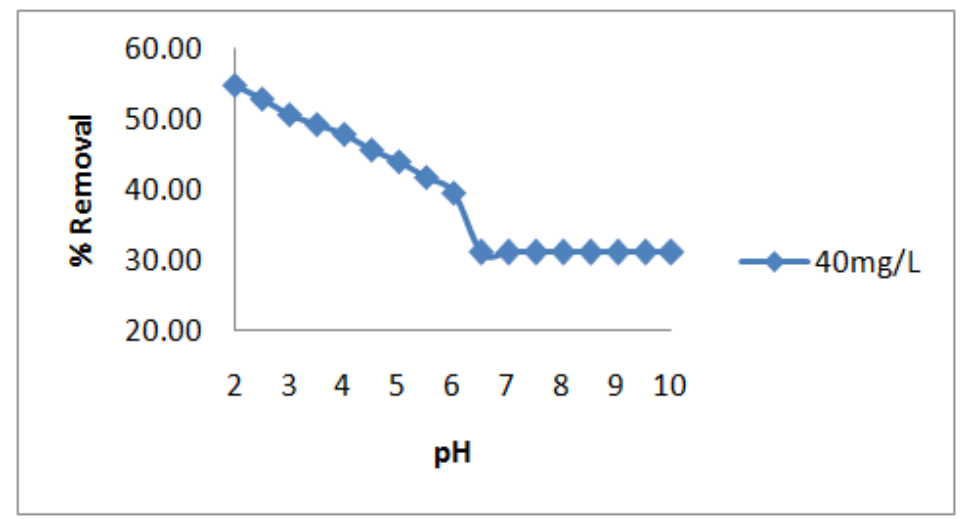

Fig.3. Effect of $\mathrm{pH}$ on removal of $\mathrm{CR}$ by $\mathrm{PAC}-\mathrm{MnO}_{2}-\mathrm{NC}$

\subsection{Effect of Temperature}

The effect of temperature of adsorption of CR (Fig.4) for concentration $40 \mathrm{mg} / \mathrm{L}$ adsorbent was carried out at $30^{\circ}, 40^{\circ}$ and $50^{\circ} \mathrm{C}$. The percent removal of dye increased from 20.66 to 64.53 . This indicates that increase in adsorption with increase in temperature may be due to increase in the mobility of the large dye ions. Moreover, increasing temperature may produce a swelling effect within the internal structure of the adsorbent, penetrating the large dye molecule further.

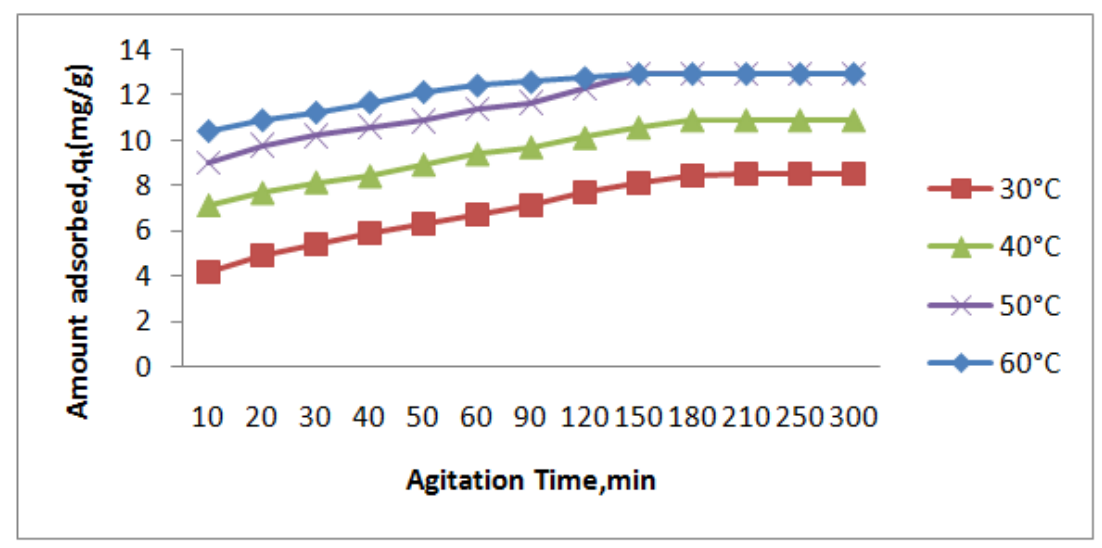

Fig.4. Effect of temperature on removal of CR by PAC-MnO ${ }_{2}-\mathrm{NC}$ 


\section{Adsorption Kinetics}

A study of adsorption kinetics is desirable as it provides the information about the mechanism of adsorption, which is important for efficiency of the process. The pseudo first-order, pseudo second-order, Intraparticle diffusion and Elovich adsorption models were used to test dynamical experimental data.

\subsection{Pseudo first order model}

The linear form of Langergren's first order rate equation is as follows [14],

$$
\log \left(\mathbf{q}_{\mathrm{e}}-\mathbf{q}_{\mathbf{t}}\right)=\log \mathbf{q}_{\mathrm{e}}-\frac{k_{1}}{2.203} t
$$

where $\mathrm{q}_{\mathrm{e}}$ and $\mathrm{q}_{\mathrm{t}}$ are the amounts of dye adsorbed on adsorbent at equilibrium and at time $\mathrm{t}$, respectively (mg/g) and $k_{1}$ is the rate constant of first order adsorption $\left(\mathrm{min}^{-1}\right)$. The slope and intercept of plot of log $\left(\mathrm{q}_{\mathrm{e}}-\mathrm{q}_{\mathrm{t}}\right)$ vs $\mathrm{t}$ were used to determine $k_{1}$ and $q_{e}$ (Fig 5). These values are shown in Table 1. It is does not fit for pseudo first order kinetics.

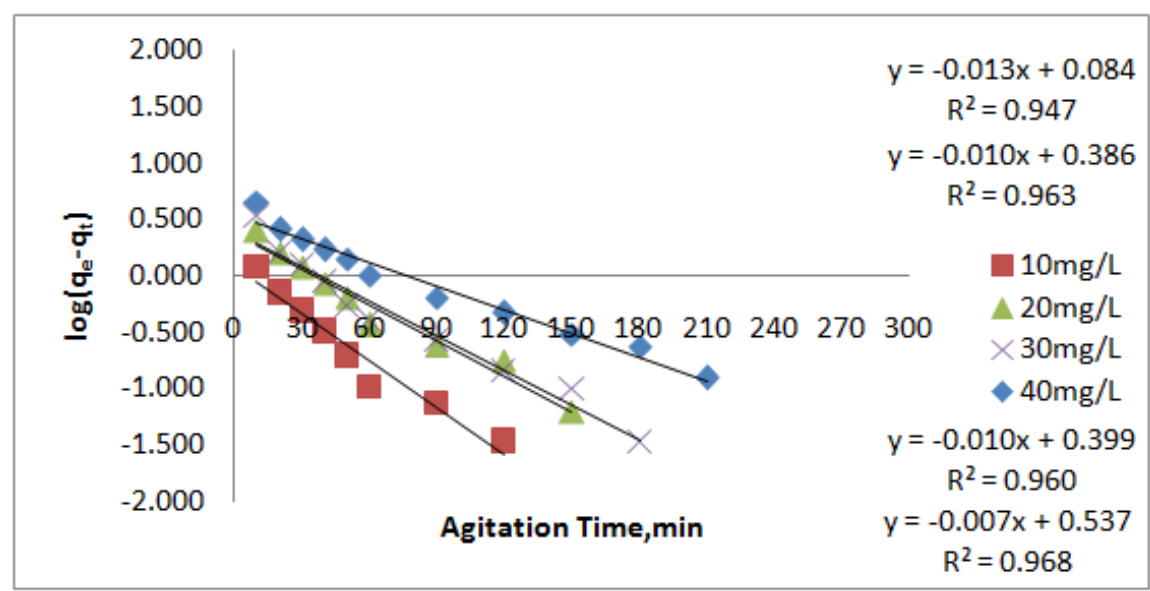

Fig.5.Plot of pseudo first order model at different concentrations

Table 1: Pseudo First order Kinetic Parameters for the adsorption of CR by PAC- $\mathrm{MnO}_{2}-\mathrm{NC}$ at various concentrations

\begin{tabular}{|c|c|c|c|c|}
\hline \multirow{2}{*}{$\begin{array}{l}\text { Initial } \\
\text { Concentrati } \\
\text { on of dye } \\
(\mathrm{mg} / \mathrm{L})\end{array}$} & \multirow[t]{2}{*}{$\begin{array}{l}q_{\mathrm{e}} \text { expt. } \\
(\mathrm{mg} / \mathrm{g})\end{array}$} & \multicolumn{3}{|c|}{$\begin{array}{l}\text { Pseudo First-order } \\
\text { Kinetics }\end{array}$} \\
\hline & & $\begin{array}{l}\mathrm{q}_{\mathrm{e}} \text { cal. } \\
(\mathrm{mg} / \mathrm{g})\end{array}$ & 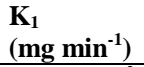 & $\mathbf{R}^{2}$ \\
\hline 10 & 3.55 & 1.2133 & $2.299 \times 10^{-2}$ & 0.947 \\
\hline 20 & 6.74 & 2.4322 & $2.303 \times 10^{-2}$ & 0.963 \\
\hline 30 & 8.94 & 2.5061 & $2.303 \times 10^{-2}$ & 0.960 \\
\hline 40 & 10.88 & 3.4434 & $1.612 \times 10^{-2}$ & 0.968 \\
\hline
\end{tabular}

\subsection{Pseudo second order model}

The linearised form of the pseudo second order model as given by Ho [15] is

$$
\frac{t}{q_{t}}=\frac{1}{k_{2} q_{e}{ }^{2}}+\frac{t}{q_{e}} \mathbf{t}
$$

where $\mathrm{k}_{2}$ is the rate constant of Pseudo-second order adsorption $\left(\mathrm{gm}^{-1} \mathrm{~min}^{-1}\right)$ and $\mathrm{q}_{\mathrm{e}}$ is the maximum adsorption capacity $\left(\mathrm{mgg}^{-1}\right)$. The slope of the plot $t / \mathrm{q}_{\mathrm{t}}$ vs $\mathrm{t}$ gives the value of $\mathrm{q}_{\mathrm{e}}$ and from intercept $\mathrm{k}_{2}$ can be calculated (Fig 6). These values are shown in Table 2. It is clear from the nature of fit and correlation coefficients that the adsorption of $\mathrm{CR}$ on PAC- $\mathrm{MnO}_{2}-\mathrm{NC}$ is better represented by Pseudo-second order kinetics. 


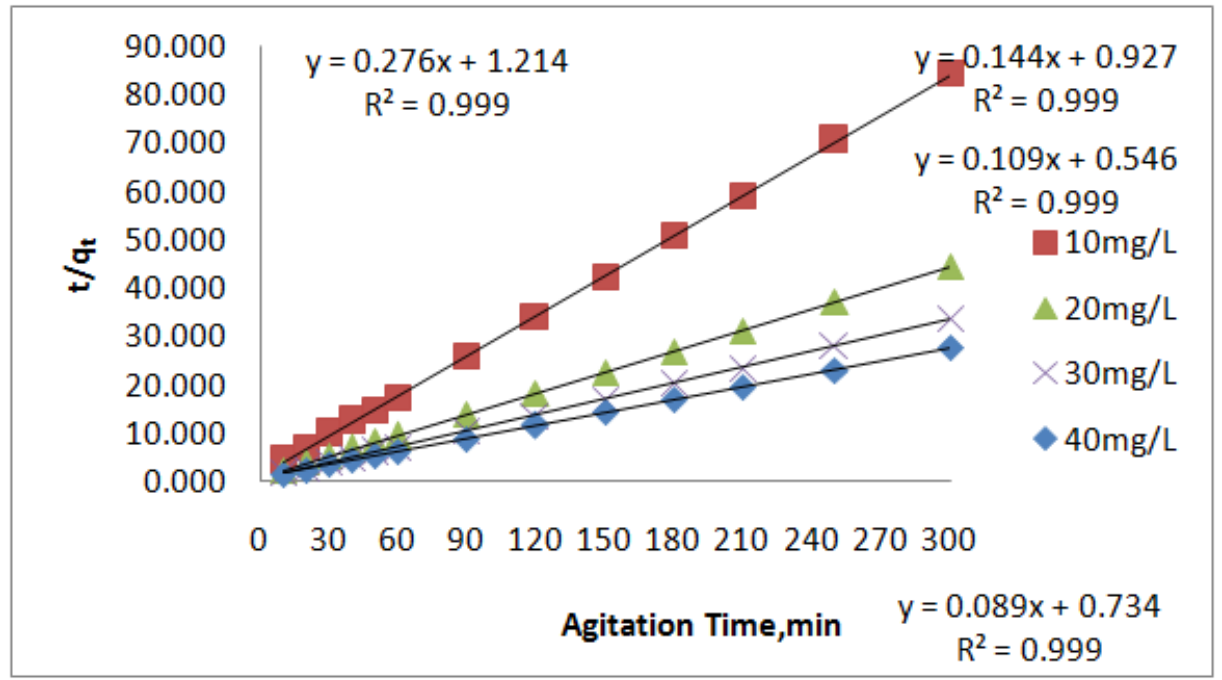

Fig. 6. Plots of the pseudo-second order model at different concentrations

Table 2: Pseudo second order Kinetic Parameters for the adsorption of CR by $\mathrm{PAC}-\mathrm{MnO}_{2}-\mathrm{NC}_{\text {at various }}$ concentrations

\begin{tabular}{|c|c|c|c|c|}
\hline \multirow{2}{*}{$\begin{array}{l}\text { Initial } \\
\text { Concentration } \\
\text { of dye }(\mathrm{mg} / \mathrm{L})\end{array}$} & \multirow[t]{2}{*}{$\begin{array}{l}\mathrm{q}_{\mathrm{e}} \text { expt. } \\
\text { (mg/g) }\end{array}$} & \multicolumn{3}{|c|}{$\begin{array}{l}\text { Pseudo Second-order } \\
\text { Kinetics }\end{array}$} \\
\hline & & $\begin{array}{l}\mathrm{q}_{\mathrm{e}} \text { cal. } \\
(\mathrm{mg} / \mathrm{g})\end{array}$ & $\begin{array}{l}\mathbf{k}_{2} \\
\left(\mathbf{m g ~ m i n}^{-1}\right)\end{array}$ & $\mathbf{R}^{2}$ \\
\hline 10 & $\mathbf{3 . 5 5}$ & 3.6231 & $0.6275 \times 10^{-1}$ & 0.999 \\
\hline 20 & 6.74 & 6.9444 & $2.236 \times 10^{-2}$ & 0.999 \\
\hline 30 & 8.94 & 9.1743 & $2.176 \times 10^{-2}$ & 0.999 \\
\hline 40 & 10.88 & 11.2359 & $1.0791 \times 10^{-2}$ & 0.999 \\
\hline
\end{tabular}

\subsection{Elovich kinetic model}

A simplified linearized form of Elovich kinetic equation [16] is presented as follows:

$$
\mathbf{q}_{\mathbf{t}}=\mathbf{1} / \square \ln (\square \square)+\mathbf{1} / \square \ln (\mathbf{t}) \quad \ldots . . . . . . . . . .4 .4 \gamma
$$

where $\alpha$ is the initial adsorption rate $(\mathrm{mg} / \mathrm{g} / \mathrm{min}), \beta$ is the desorption constant $(\mathrm{g} / \mathrm{mg})$ during any one experiment. A plot of $q_{t}$ versus $\ln (t)$ with a straight line, as expected, with a slope of $(1 / \beta)$ and an intercept of $(1 / \beta) \ln (\alpha \beta)$ can be calculated in Fig.7. The elovich model parameters $\alpha, \beta$ and correlation coefficient $\mathrm{R}^{2}$ are summarized in Table 3. From the table the intial adsorption rate $(\alpha)$, desorption constant $(\beta)$ and the correlation coefficient $\left(\mathrm{R}^{2}\right)$ are calculated. The correlation coefficient is $\left(\mathrm{R}^{2}\right)$ is less than that of Pseudo second order model.

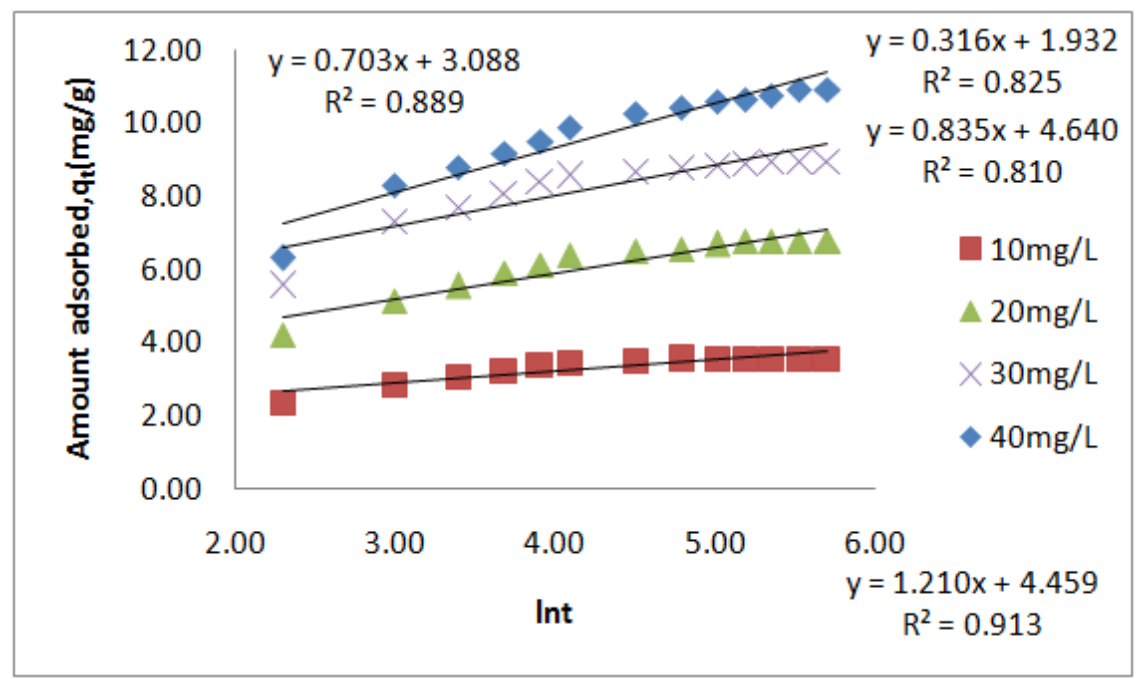

Fig.7. Elovich kinetic model of $\mathrm{CR}$ by $\mathrm{PAC}-\mathrm{MnO}_{2}-\mathrm{NC}$ 


\subsection{Intraparticle diffusion model}

The intra particle diffusion model is used here refers to the theory proposed by [17] the following equation for the rate constant:

$$
\mathbf{q}_{\mathrm{t}}=\mathbf{k}_{\mathrm{id}} \mathbf{t}^{0.5}+\mathbf{C}
$$

Where $\mathrm{K}_{\mathrm{id}}$ is the intra particle diffusion rate constant $\left(\mathrm{mg} / \mathrm{g} \mathrm{min}^{-1 / 2}\right)$ and $\mathrm{C}$ is constant. If that rate limiting step is intra particle diffusion, the graphical representation of adsorbed dye $q_{t}$ versus $t^{0.5}$ yield straight lines passing through the origin and the slope gives the intra particle diffusion rate constant $k_{i d}$ and correlation coefficient $\left(R^{2}\right)$ is indicated in Fig. 8.

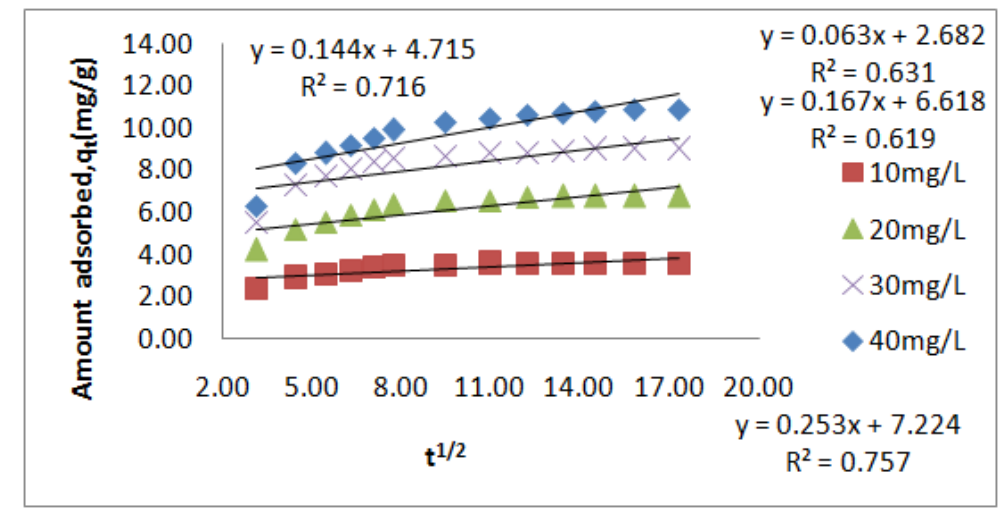

Fig. 8. Intraparticle diffusion model kinetic model of CR by $\mathrm{PAC}-\mathrm{MnO}_{2}-\mathrm{NC}$

The intra-particle parameters $\mathrm{K}_{\mathrm{id}}, \mathrm{C}$ and correlation co-efficients $\mathrm{R}^{2}$ are summarized in Table 3. From these data inter set value indicate that the line are not passing through origin, therefore some other process that may affect the adsorption. The correlation coefficient $\left(\mathrm{R}^{2}\right)$ value is less than that of Pseudo second order model.

Table 3: Elovich and Intraparticle diffusion Model of CR by $\mathrm{PAC}-\mathrm{MnO}_{2}-\mathrm{NC}$

\begin{tabular}{|l|l|l|l|l|l|l|}
\hline \multirow{2}{*}{\begin{tabular}{l} 
Initial Dye Concentration $(\mathbf{m g} / \mathrm{L})$ \\
\cline { 2 - 7 }
\end{tabular}} & \multicolumn{3}{|l|}{ Elovich Model } & \multicolumn{3}{l|}{ Intraparticle diffusion Model } \\
\hline 10 & $\square$ & $\square$ & $\mathbf{R}^{2}$ & $\mathbf{K}_{\text {id }}$ & $\mathbf{C}$ & $\mathbf{R}^{2}$ \\
\hline $\mathbf{2 0}$ & $\mathbf{1 4 2 . 8 6 4}$ & $\mathbf{3 . 1 6 4 5}$ & $\mathbf{0 . 8 2 5}$ & $\mathbf{0 . 0 6 3}$ & $\mathbf{2 . 6 8 2}$ & $\mathbf{0 . 6 3 1}$ \\
\hline $\mathbf{3 0}$ & $\mathbf{5 6 . 8 0 9 2}$ & $\mathbf{1 . 4 2 2 4}$ & $\mathbf{0 . 8 2 5}$ & $\mathbf{0 . 1 4 4}$ & $\mathbf{4 . 7 1 5}$ & $\mathbf{0 . 7 1 6}$ \\
\hline $\mathbf{4 0}$ & $\mathbf{2 1 6 2 . 2 6}$ & $\mathbf{1 . 1 9 7 6}$ & $\mathbf{0 . 8 1 0}$ & $\mathbf{0 . 1 6 7}$ & $\mathbf{6 . 6 1 8}$ & $\mathbf{0 . 6 1 9}$ \\
\hline
\end{tabular}

Adsorption kinetics and isotherms are very important information for adsorption process design. Compared with the pseudo-first order, Elovich, Intraparticle diffusion model, the pseudo-second order kinetic model was found to fit the dye adsorption kinetic data more appropriately. Although many different adsorbents are tried to remove dyes from wastewaters, activated carbon from various sources is still the most widely used adsorbent for color removal.

\section{Thermodynamic Parameter}

Thermodynamic parameters like $\Delta \mathrm{H}^{\mathrm{o}}$ and $\Delta \mathrm{S}^{\mathrm{o}}$ were evaluated using Van't Hoff's equation:

$$
\ln \mathbf{K}_{\mathbf{c}}=\square \mathbf{S}^{\mathbf{o}} / \mathbf{R} \square \mathbf{H}^{\mathbf{o}} / \mathbf{R T} \text {. }
$$

Where $\mathrm{K}_{\mathrm{c}}$ is the Langmuir equilibrium constant, $\Delta \mathrm{H}^{\circ}$ and $\Delta \mathrm{S}^{\circ}$, are the standard enthalpy and entropy changes of adsorption respectively and their values are calculated from the slopes and intercepts respectively of the linear plot of $\ln \mathrm{K}_{\mathrm{c}}$ Vs 1/T. The free energy change for the adsorption process $\Delta \mathrm{G}^{\mathrm{o}}(\mathrm{kJ} / \mathrm{mol})$ is derived in equation 7 .

$$
\square \mathbf{G}^{\mathbf{o}}=\square \mathbf{H}^{\mathbf{0}} \mathbf{T} \square \mathbf{S}^{\mathbf{0}} \text {... }
$$

The values of these parameters were calculated using equation $(6 \& 7)$ at various initial Concentrations and are shown in Table 4.

Table 4: Thermodynamic parameters for the adsorption of CR by $\mathrm{PAC}-\mathrm{MnO}_{2}-\mathrm{NC}$

\begin{tabular}{|l|l|l|l|l|l|}
\hline $\begin{array}{l}\square \mathbf{G}^{\mathbf{0}} \\
(\mathrm{kJ} / \mathrm{mol})\end{array}$ & $\begin{array}{l}\square \mathbf{S}^{\mathbf{0}} \\
(\mathrm{J} / \mathrm{mol} / \mathrm{K})\end{array}$ & $\begin{array}{l}\square \mathrm{H}^{\mathbf{0}} \\
(\mathrm{kJ} / \mathbf{m o l})\end{array}$ \\
\cline { 1 - 4 } $\mathbf{3 0 3 K}$ & $\mathbf{3 1 3 K}$ & $\mathbf{3 2 3 ~ K}$ & $\mathbf{3 3 3 ~ K}$ & $\mathbf{8 3 . 8 8 8 2}$ & $\mathbf{2 5 . 9 3 9 6}$ \\
\hline-25.3921 & $\mathbf{- 2 6 . 2 3 1 0}$ & $\mathbf{- 2 7 . 0 6 9 9}$ & $\mathbf{- 2 7 . 9 0 8 8}$ & & \\
\hline
\end{tabular}


The adsorption data indicates that $\Delta \mathrm{G}^{\mathrm{o}}$ were negative at all temperatures. The negative $\Delta \mathrm{G}^{\mathrm{o}}$ confirms the spontaneous nature of adsorption of $\mathrm{CR}$ by $\mathrm{PAC}-\mathrm{MnO}_{2}-\mathrm{NC}$. The magnitude of $\Delta \mathrm{G}^{\mathrm{o}}$ suggests that adsorption is physical adsorption process. The positive value of $\Delta \mathrm{H}^{\circ}$ were further confirms the endothermic nature of adsorption process. The positive $\Delta \mathrm{S}^{\mathrm{o}}$ showed increased randomness at the solid-solution interface during the adsorption of CR dye by PAC- $\mathrm{MnO}_{2}-\mathrm{NC}$. This was also further supported by the positive values of $\Delta \mathrm{S}^{\circ}$, which suggest that the freedom of CR is not too restricted in the adsorbent, confirming a physical adsorption. The $\Delta \mathrm{G}^{\circ}$ value increases with increase in temperature is the increase in enhancement of the adsorption capacity of adsorbent may be due to increase or enlargement of pore size and/or activation of the adsorbent surface.

\section{Desorption Studies}

After activated carbon is saturated with dye molecules, different solvents could be used to regenerate the activated carbon to restore its dye adsorptive capability [18]. Desorption with acetic acid revealed that the regeneration of adsorbent was satisfactory, which confirms the physisorptive nature of adsorption.

\section{Conclusions}

The present study shows that $\mathrm{PAC}-\mathrm{MnO}_{2}-\mathrm{NC}$ is an effective adsorbent for the removal of CR from aqueous solution. The thermodynamic parameters were found to be thermodynamically favourable physical adsorption process. Evaluation of thermodynamic parameters showed the process as endothermic and spontaneous. The kinetic parameters fit for Pseudo second order model. Desorption studies reveals that satisfactory desorption taking place confirming physisorptive nature of adsorption. Complete removal of the dye can be achieved using an appropriate dosage of the adsorbent and $\mathrm{pH}$ for waste waters. The results would be useful for the fabrication and designing of waste water treatment plants for the removal of dye. Since the raw material is freely available in large quantities the treatment method, seems to be economical.

\section{References}

[1]. W.C., Tincher, Enhanced Rates of photocatalytic Degradation of an Azo Dye using $\mathrm{SnO}_{2} /$ Ti $\mathrm{O}_{2}$ Coupled semiconductor Thin flims. Text Chem color. 21, 1989, 33

[2]. M.T.,Yagub, T.K.,Sen, H.M.,Ang, Equilibirium, kinetics and thermodynamics of methylene blue adsorption by Pine tree leaves. Water, Air, Soil Pollution, 223, 2012, 5267-5282.

[3]. V.,Gupta, V.,Suhas, Application of low-cost adsorbent for dye removal: a review. J.Environ.Manage. 90, $2009,2313-2342$.

[4]. [4]. B.,Benguella, A., Yacouta - Nour, Adsorption of Bezanyl Red and Nylomine Green from aqueous solutions by natural and acid - activated bentonite. Desalination, 235, 2009, 276-292.

[5]. E.1.,Haddad, M., Mamouni, R., Saffaj, and S., Lazar, Global. J.Human Soc. Sci.

[6]. M., Abul Hossain, R.M., Afiqur, Orbital Elec. J. Chem. Campo Grande, 4(3), 2012,187-201.

[7]. C., Theivarasu, S., Mylsamy, Int. J. Eng .Sci.Technol, 2(11), 2010, 6284-6292.

[8]. M.,Aliabadi, I., Khazari, M.,Hajiabadi, and F.,Shahrzad, J. Bio \& Env. Sci., 2(9), 2012, 39-44

[9]. T.A.,Khan, S.,Sharma, and I.,Ali, J. Toxicol. Environ. Health Sci., 3(10), 2011, 286-297.

[10]. A.,Wttek-Krowiak, M., Mittek, K.,Pokomeda, and R.G., Szafran and S., Modelski, Chem. Process Eng., 31, 2010, 409-420.

[11]. P.E.,Kumar, Studies on characteristics and Fluoride removal capacity of Jambonut Carbon. M.Phil., Disseration: Bharathiar University, Coimbatore, Tamilnadu, India, 1991.

[12]. P.E., Kumar, V., Perumal, ost Novel Adsorbent Derived from the Inflorescence of Palmyra (Borassus flabellifer L.) Male Flowers. Nature Environment and Pollution, 9 [3] 2010, 513-518.

[13]. M., Santhi, P.E., Kumar and B., Murlidharan, Removal of Malachite Green Dyes By Adsorption onto Activated Carbon -MnO ${ }_{2}-$ Nanocomposite -Kinetic Study and Equilibrium Isotherm Analyses,J. Appl. Chem., 8, 2015, 33.

[14]. S., Langergren, Kungliga Svenskavetenskapsakademies. Handlinger. $24,1898,1$.

[15]. Y.S.,Ho, G., Mckay, Water Research,34, 2000, 735.

[16]. D.L., Sparks, Kinetics of Reaction in pure and mixed systems in soil physical chemistry. CRC press, BocaRaton.1986.

[17]. W.J.,Weber, J.C.,Morris, Journal of Sanitary Engineering Division. 90,1964,79.

[18]. X., Bai, F.S.,Yuan, T., Zhang, J,X.,Wang, H.,Wang and W.,Zhang, Joint effect of Formaldehyde and xylene on mouse bone marrow cells. Journal of Environment and Health. 29(1), 2012, 51-54. 